\title{
Do Customer Dissatisfaction and Variety Seeking Really Affect the Product Brand Switching? A Lesson from the Biggest Southeast Asia Mobile Telecommunication Market
}

\author{
Uturestantix $^{1}$, Ari Warokka ${ }^{2}$ and Cristina Gallato ${ }^{2}$ \\ ${ }^{1}$ Faculty of Economics - Cendrawarsih University, Indonesia \\ ${ }^{2}$ College of Business - UUM, Malaysia
}

\begin{abstract}
As the 21st century world would be a cellular age going by the phenomenal increase in cell phones worldwide, the Southeast Asia's market is experiencing a tremendous growth of mobile penetrations in the context of a region for developing countries with large population concentration. The mobile revolution has triumphed in Southeast Asia and become the key hub of the world's mobile \& telecom market in terms of penetration and innovation, and promoted the best of mobile-based implementations in the region Asia. Therefore, as the competition becomes more intensified, it is important to any companies to anticipate any changes in its customers' preferences, especially all variables related to the customer dissatisfaction and varieties seeking that are much revealed in prior studies. This study has two objectives; firstly, it aims to examine the effect of consumer dissatisfaction, variety seeking, and sales promotions simultaneously on brand switching. Secondly, it will explore a further relationship, which is rarely investigated in prior studies, between consumer dissatisfaction and brand switching, which is moderated by the variety seeking. By using 240 respondents in the 2010-GSM prepaid cards' market situation, we used logistic regression to analyze the data. The results reveal that consumer dissatisfaction and sales promotion are significantly positive related to brand switching. The variety seeking moderates the effect of consumer dissatisfaction on brand switching, and as the moderating variable, the variety seeking has weakened the effect of consumer dissatisfaction on brand switching.
\end{abstract}

Keyword: Consumer Dissatisfaction, Variety Seeking, Sales Promotions, Brand Switching.

\section{Introduction}

Recently, the brand switching decision phenomenon has led to a decreased level of companies' income, especially in case of GSM (Global System for Mobile Communications, originally Groupe Spécial Mobile) prepaid card products. It causes the declining number of 20 percent subscribers, which is reflected by the churn rate (charred number) each month (Achmad, 2011). Therefore, it is very important for companies to know and understand the variables influencing on consumers' brand switching decision.

Prior empirical studies reveal that consumer dissatisfaction is the cause of consumers' brand switching (Sambandam and Lord,

Copyright (C) 2012 Uturestantix, Ari Warokka and Cristina Gallato. This is an open access article distributed under the Creative Commons Attribution License unported 3.0, which permits unrestricted use, distribution, and reproduction in any medium, provided that original work is properly cited. Contact author: Uturestantix E-mail: uturestantix@yahoo.com 
1995). However, Assael (2004) finds that consumers switch brands it is not because they are not satisfied, but because they want to try something new. Someone who is searching for brand variation is not always driven by his/her dissatisfaction of the used previous brands (Raju, 1980; David, Barbera, and Aiello, 1996). Other studies find that the variation needs have moderated the effect of consumer dissatisfaction on the decision of brand switching (Junaedy and Dharmmesta, 2002), while Setiyaningrum (2006) reports that the variation needs do not moderate the effect of consumer dissatisfaction on brand switching decision when it is applied to different products.

Prior empirical findings also reveal that sales promotion variable is given less attention as the influencing factor (Sambandam and Lord, 1995; Van Trijp, Hoyer, and Inman, 1996; Junaedy and Dharmmesta, 2002; Setiyaningrum, 2006), even though Nagar (2009) reports that sales promotions have a significant effect on brand switching decision. It is important to include sales promotion into the model of brand switching influencing factors due to the empirical finding of Van Heerde, Gupta, and Wittink (2003), which report that $30 \%$ of sales promotion influences brand switching. By using the coffee category and three components of household response (i.e. category purchase timing, brand choice, and purchase quantity), Gupta (1988) also finds similar finding that shows the percent of the own-brand sales elasticity with respect to a particular promotion due to the brand switching elasticity is 84 percent. He also notes that such decomposition may be used to compare the effectiveness of alternative promotional offerings and to determine the most suitable promotion for a brand.

To our knowledge, few empirical studies in brand switching decision are done in emerging markets, such as in Indonesia. Therefore, this study seeks to bridge this gap by integrating altogether three variables into one model; thus, it will be able to add empirical support on the theory underlying it, in the context of fast-growing product category-based on technology used. Our research objective is to examine the effect of consumer dissatisfaction, the need to seek variations, and sales promotions on brand switching decision, in the context of GSM prepaid card product.

\section{Research Question}

Then lastly known and recorded empirical studies on consumer dissatisfaction, product category characteristics, and the need to seek the variation, in particular, are done in emerging markets, such as in Indonesia and India, reveal that there are the inconsistencies of the relationship between those variables. It can be seen in Table 1 . 
Table 1: Prior Studies of the Effects of Consumer Dissatisfaction, Product Category Characteristics, and the Need to Seek Variations in Indonesia (since 2002)

\begin{tabular}{|c|c|c|c|c|}
\hline No. & Author(s) & Variables & Product(s) & Results \\
\hline 1 & $\begin{array}{l}\text { Junaedy and } \\
\text { Dharmmesta } \\
(2002)\end{array}$ & $\begin{array}{l}\text { Consumer } \\
\text { dissatisfaction } \\
\text { Product category } \\
\text { characteristics } \\
\text { The need to seek } \\
\text { variations }\end{array}$ & $\begin{array}{l}\text { Toiletries (bath } \\
\text { soap, shampoo, } \\
\text { tooth paste) }\end{array}$ & $\begin{array}{l}\text { Consumer dissatisfaction and } \\
\text { the need to seek variations } \\
\text { have significantly influenced } \\
\text { on brand-switching decision. } \\
\text { Product category } \\
\text { characteristics do not affect } \\
\text { brand-switching decision. } \\
\text { The need to seek variations } \\
\text { moderates the effects of } \\
\text { consumer dissatisfaction and } \\
\text { product characteristics } \\
\text { category on brand-switching } \\
\text { decision. }\end{array}$ \\
\hline 2 & $\begin{array}{l}\text { Setiyaningrum } \\
(2006)\end{array}$ & $\begin{array}{l}\text { Consumer } \\
\text { dissatisfaction } \\
\text { The need to seek } \\
\text { variations }\end{array}$ & $\begin{array}{l}\text { Cosmetics (solid } \\
\text { powder, facial } \\
\text { milk cleanser, } \\
\text { facial soap) }\end{array}$ & $\begin{array}{l}\text { Consumer dissatisfaction and } \\
\text { the need to seek variations } \\
\text { have significantly influence } \\
\text { on brand-switching decision. } \\
\text { The need to seek variations } \\
\text { does not moderate the effect } \\
\text { of consumer dissatisfaction } \\
\text { on brand-switching decision. }\end{array}$ \\
\hline 3 & Nagar (2009) & Sales promotion & $\begin{array}{l}\text { Detergent soap } \\
\text { and shampoo }\end{array}$ & $\begin{array}{l}\text { Sales promotion has } \\
\text { significantly influenced on } \\
\text { brand-switching decision }\end{array}$ \\
\hline
\end{tabular}

Based on those facts, our study is trying to bridge the inconsistencies of the moderating effect of the need to seek the variation on the relationship of consumer dissatisfaction and product category characteristics on brandswitching decision, by using GSM prepaid cards, which are totally different from prior studies' product categories. The reason of using GSM prepaid cards as brand-switching object is based on the fantastic-growing number of cellular phone in Indonesia has achieved 180 million customers just within 15 years since GSM service provider started to operate in 1995 (Wahono, 2010). 95 percent of those customers are prepaid card users. The market of GSM prepaid card is one of the most intensified competitions, which is characterized by the increasing and continuously innovative features available for prepaid cards, user-friendly design, and very low price. The main segment of GSM prepaid card is students and young people comprising 60 percent of total GSM prepaid cards' customers (Yandiana, 2008), which are identified as price concerned and new features-loving customers. This situation, of course, has put GSM prepaid cards' operators into a hyper-competitive market that is vulnerable to the customers' brand-switching actions.

We expect that the change of product category characteristics, which are previously taken from daily used and low involved product category to price concerned and dynamic technology change-sought one, it triggers the moderating effect of the need to seek to variation on the relationship between consumer dissatisfaction and brand-switching decision. We also examine the simultaneous effect of these three independent variables, i.e. consumer 
dissatisfaction, the need to seek variations, and sales promotion on the brand-switching model. In prior studies, the test of this kind of relationship was done separately and individually.

\section{Literature Review}

Consumer purchasing activity is one phase of the overall process of consumer's mental and other physical activities that occur in the buying process in a given period. Firstly, consumers will try to find information related to the products that are needed and wanted. Secondly, consumers make the selection on the available alternatives. Then, after watching a variety of alternatives, the consumers choose one brand and make the purchasing decisions. Finally, consumers will conduct the post-purchase evaluation. From the final process, a consumer can determine whether he/she is satisfied or not. This process will continue repeatedly until consumers feel satisfied with their product purchasing decision (Assael, 2004).

Referring to the last stage of consumer purchasing decision, consumer dissatisfaction occurs when brand of a specified product, which is considered to meet the consumers' needs and desires, produces an opposite state after the consumers have used and assessed the expected benefits of that product. These unsatisfied consumers will try to find information or options of other products that have added value and in line with their expectations, and they may stop buying that product or even influence others not to buy. Therefore, companies should strive to improve customer satisfaction, so they become loyal, and if marketers are not able to provide the needs and desires of consumers or in other words, consumer satisfaction, it can cause consumers to switch the brands.

To understand consumer dissatisfaction, it is important to get clear comprehension of satisfaction. Satisfaction is "a person's feelings of pleasure or disappointment resulting from comparing products perceived performance (or outcome) in relation to his or her expectations" (Kotler and Keller, 2009). Hoyer and MacInnis (2001) said that satisfaction can be associated with feelings of acceptance, happiness, relief, excitement, and delight. The consumer will feel happy and satisfied if a brand of product can meet his or her needs and desires, otherwise, he/she will feel disappointed and certainly does not feel the satisfaction. Another study defines satisfaction as consumers' overall evaluation of the supply performance (Gustafssons, Johnson, and Roos, 2005), so if consumers perceive that the overall evaluation on the supply performance is not good, then consumers will feel no satisfied. According to Lau and Lee (1999), satisfaction is defined as customers' subjective evaluation on their selected choices, whether it meets or exceeds their expectation. In the context of certain product, i.e. GSM prepaid cards, satisfaction is the result of subjective evaluation of customers whether the selected service providers of GSM prepaid cards could meet or exceed their expectation, so if the results of customers' subjective evaluation on selected GSM prepaid card service provider cannot meet or exceed their expectation, then the customer will be dissatisfied.

Marketers need to identify customers who like to try new products. It is because they can be the pioneers who help the company in offering new products (Junaedy and Dharmmesta, 2002). The need of the variety seeking is a behavior that is not always caused by discontent alone, but also it is seen as a manifestation of the consumers' desire to conduct exploration in purchasing behavior (Raju, 1980). In terms of individual differences' characteristics, personality traits and motivational factors are the factors that potentially lead to the need to find variation. A synthesis of previous research suggests that a number of specific (yet interrelated) motives may combine to produce a general variety drive. The most basic motive is the need for change (Leuba 1955), the need for new and unfamiliar stimuli (Penny and Reinehr 1966), the need for excitement and thrills (Zuckerman et al. 1964), the need for 
arousal (Mehrabian and Russell 1974), and a preference for irregularity (Garlington and Shimota 1964). According to Van Trijp et al. (1996), this need can be divided into two, namely true variety seeking behavior (intrinsic factors) and derived-varied behavior (extrinsic factors). This categorization is made to examine whether the displacement behavior brand is motivated intrinsically or extrinsically. The need to find variations is the intrinsic factor that it could cause consumers to make brand switching (Degeratu, 1999). Prior empirical findings reveal that the need of the variety seeking affects the brand in certain brand or product (Howard, 1989; Hawkins and Hoch, 1992).

After creating a product, a company needs to promote it, or in other words, it should do marketing activities to inform and introduce new products to its consumers/customers. The goals are to get customers/consumers' acceptance on that products or service, and then they would like to use it. One of the promotion types is sales promotion that consists of a collection of marketing different incentives, mostly in short term, which is designed to encourage a faster and larger consumer/customer's purchasing on particular products (Kotler and Keller, 2009). Prior studies have reported the important role played by promotion in influencing consumer behavior (Sood and Kathuria, 2005). Even though generally, the sales promotion is viewed as a destructive tool in promoting certain brands (Nagar, 2009), companies believe that it must be done and is intended to accelerate sales. In many cases, sales promotion takes a big part of total marketing expenditure, and it remains as an area that still attracts attention and plays an important component of the promotion mix that is intended to increase short-term sales. Therefore, it is not surprising that most marketers use sales promotions to attract market share of competitors (Nagar, 2009). The study of Kahn and Louie (1990) reports that the effect of sales promotion on consumers who frequently make the brandswitching decisions has encouraged consumers to be attracted to the product of a certain brand, which is in a sales promotion program.

Satisfied customers normally will continue to buy, while dissatisfied customers surely will stop buying the product, then they will try to seek a replacement towards product that can meet their needs and desires. The need to find variation is not the sole cause of consumers' brand switching, but also it is influenced by several factors, such as strategy-making, situational and normative factors, dissatisfaction with the previous brand, and problem-solving strategies (Hoyer and Ridgway, 1984). According to David et al. (1996), the brand-switching behavior can be caused by intrinsic and extrinsic factors. Intrinsic factor is a factor coming from within the consumer, namely the desire to try new brands. Meanwhile, the extrinsic factors are factors that come from outside, such as the offering of free samples and discounted or a cheaper price. According to Dharmmesta (1999), the stimulation marketing on consumer will activate his cognitive stage, which is highly susceptible to the brand-switching decision. Those empirical findings define brand switching as a purchasing pattern that is indicated by the change or shift from one brand to another brand. The study of Keaveney (1995) reveals that there are some causing factors on the brand-switching decision, such as pricing policy, inconvenience, the failure of core services, lack of response of employees in addressing the failure of provided services to consumers, competitors offer more attractive services, and ethical issues.

\section{Hypotheses Development}

Cronin and Taylor (1992) argue that consumers' satisfaction or dissatisfaction will affect the intention to buy again. Satisfied customers will become loyal and want to establish ongoing relationships with companies that offer products that can satisfy consumers' needs and wants (Kotler and Keller, 2009). Thus, satisfaction is a function of perceptions of performance and 
expectations. A high level of customer satisfaction will lead to a sense of loyalty to particular brands. According to Assael (2004), dissatisfaction leads to negative attitudes toward the brand and reduces the tendency to buy the same brand, while satisfaction can strengthen the positive attitude of consumers toward a brand, and increase the propensity to repurchase the same brand. Srinivasan and Ratchford (1991) argue that the high satisfaction felt by consumers will reduce the probability that they will switch to another brand and improve their business information search. Sambandam and Lord (1995) support this prior empirical finding by revealing a negative relationship between consumer satisfaction and brand-switching behavior for automotive products. Therefore, based on those prior studies, the first hypothesis is:

\section{$\mathrm{H}_{1}$ : Consumer Dissatisfaction Has Positively Influenced Brand-Switching Decision}

In the model developed by Hoyer and Ridgway (1984), the need to seek variation is the most influenced factor in the exploration of brand switching behavior. However, this behavior is not always caused by discontent alone, but also it is seen as a manifestation of the desire of consumers to conduct exploration in purchasing behavior (Raju, 1980). According to Assael (2004), the need to seek variation occurs only in products that involve consumers' low involvement; it is because the product is not too risky for consumers. On the purchase of products that involve consumers' low involvement, consumers are just looking for information and then evaluate the options that are limited or even do not like to find information and evaluate the various brand options, so it likely moderates the relationship of need to seek variations of dissatisfied consumer and the brand switching decision. Individual motivation to seek alternatives from other manufacturers depends on individual characteristics and perceptions in assessing product characteristics that determine whether individuals seeking variations like to switch brands or not (Van Trijp et al., 1996). Junaedy and Dharmmesta (2002) find that the need to seek variations moderates the relationship between consumer dissatisfaction and the brand switching decision in toiletries products, which fall into the category of products that involve consumers' low involvement. Therefore, based on those arguments, the second hypothesis is:

\section{$\mathrm{H}_{2}$ : The Need to Seek Variation Moderates the Influence of Consumer Dissatisfaction on the Brand Switching Decision}

Due to the important role of promotions in marketing strategy, marketers and researchers are very involved to enhance further their understanding on how sales promotion affects consumers' loyalty to certain brand referring to the characteristics of customers who will only buy products from a particular brand rather than switch to an alternative brand (Lin et al., 2000). Raju and Hastak (1983) examined the effects of promotion on the purchasing transaction, and the results showed that the promotions not only have a positive effect on intention to try the brand, but they also serve as an effective element of blocking negative thoughts that may arise about the brand. Another empirical finding reveals that the possibility of brand switching increases as the increase of deal size. This means that sales promotion encourages a positive effect when it is in the form of the economic incentives that push consumers to obtain the discounts and thus feel like a "smart" shopper (Schindler, 1984). Therefore, based on those arguments, the third hypothesis is:

\section{$\mathrm{H}_{3}$ : Sales Promotion Has Positive Effect on Brand Switching Decision}

From Figure 1, the basic idea of the study as follows, the independent variable, namely consumer dissatisfaction has positive influence on brand switching decision. Then sales promotion also has positive influence on brand switching decision. Meanwhile, the need to find variation variable moderates the 
relationship between consumer dissatisfaction and brand switching decision, if the level is low, the needs to find variations of unsatisfied customers will do the brand switching decision. In this context, the moderating effects of low need to find variation will strengthen the influence of consumer dissatisfaction to make the brandswitching decisions. On the other hand, at the high level of needs to find variations, the consumers will make brand-switching decisions, even though they are satisfied.

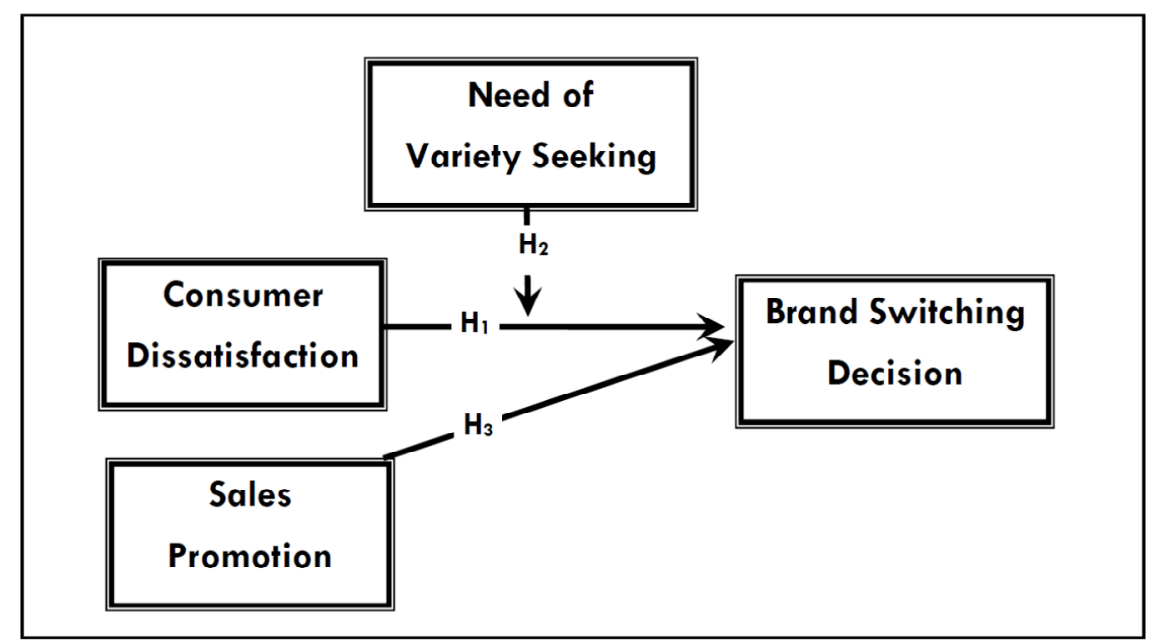

Fig. 1: Research Model of the Relationship of Consumer Dissatisfaction, Sales Promotion, Need of Variety Seeking, and Brand Switching Decision

\section{Research Methodology}

The object of this research is GSM prepaid card product. It is because GSM prepaid cards are capable of capture the phenomenon of needs to find variation in price concerned and dynamic technology change-sought product category. This product category is different from the ones that had been used in prior studies. According to Assael (2004), the need to find variations only occurs on the products that have consumers' low involvement, because the products are not too risky for consumers. It happens because consumers are just looking for information and then evaluate the limited options. GSM prepaid cards in Indonesia fulfill the basic requirements of consumers' low involvement characteristics that support the need of finding variation, such as the $20 \%$ churn rate number per month, the relatively cheap price (USD 0.5-1.0), the emergence of dual SIM card cellular phone technology, and the low level of risk.
The respondents in this research are 240 university students divided into two age categories, i.e. $18-24$ and $25-35$ years. The selection of respondents by age category in this research is based on the prior study that reveals consumers with 18-24 years age category have high need to find variations' level, meanwhile consumers with age category $>24$ years have the other level one (Wood, 2004). Therefore, the choice of this age category is expected to meet the study objective.

\section{Measurement of Research Instruments}

In this study, we adopted a measurement instrument that has been developed and tested its validity and reliability in prior studies. This measurement contains a set of indicators measuring the variables in the form of questions. We used five-point Likert scale for each item question. To measure the customer dissatisfaction, there are five items taken from the question of satisfaction 
measure developed by Oliver (1980). Five items will be assessed in a Likert scale with a score from 1 to 5, i.e. ranging from Strongly Disagree until Strongly Agree (SS).

To measure the needs to find variation variable, we use eight items taken from the scale question of Exploratory Acquisition of Product (EAP), which is used to measure the trend of consumers' looking for stimulation in the purchase of products. These items are also taken from measurement developed by Baumgartner and Steenkamp (1996), which measure need of the variety seeking through the selection of varied innovative products and the changing of consumers' purchasing experience when they consume the product. Each item question is assessed in Likert Scale from a score of 1 to 5, i.e. starting from Strongly Disagree until Strongly Agree (SS).

The sales promotion variable is measured by using the 13 items developed by Nagar (2009), which are assessed in Likert scale with a score of 1 to 5, i.e. starting from Strongly Disagree (STS) until Strongly Agree (SS). Meanwhile, to measure the brand switching decision, we used a nominal scale that was based on the item question is "if one day I need a GSM prepaid card products," then I will: a) try another brand, b) keep buying the same brand. If the respondent makes the brand switching than it will be given a score of 1 , whereas if the respondent re-purchases the same brand, it will be given a score of 0 .

In this study, to test the validity of the construct used, we applied convergent validity and discriminant validity test, i.e. Confirmatory Factor Analysis (CFA) and Kaiser Meyer Olkin (KMO) and Bartiett's Test, which aim to test the presence or absence of correlation between variables. Meanwhile, to test the instrument reliability, we used Cronbach's alpha coefficient, which the research instrument is said reliable if alpha score is above 0.6 (Hair, Anderson, and Black, 2006).

We used logistic model analysis because it assumes that the outcome variable, $\mathrm{Y}$, is a category (e.g. dichotomous). Logistic regression analysis is used to determine the existence and effect of relationship between independent variables that have an interval measurement scale and the dependent variable that has a nominal measurement scale. We used logistic regression to test hypotheses 1,2 , and 3 , because there are two types variables multiple that have different measurement scales, i.e. the independent variables of consumer dissatisfaction, the need to find variations and sales promotion multiple 'that' are in interval measurement scale, and the dependent variable of brand switching decision multiple that is in nominal scale.

\section{Findings and Discussion}

The purpose of testing hypothesis 1 is to analyze the presence or absence of the effect of consumer dissatisfaction on the brand switching decision of GSM prepaid card products, and the result of logistic regression analysis as follows.

Table 2: Logistic Regression Analysis of the Effect of Consumer Dissatisfaction on Brand Switching Decision GSM Prepaid Card Products

\begin{tabular}{|c|c|c|c|c|c|c|}
\hline & B & S.E & Wald & df & Sig. & Exp(B) \\
\hline Step (1a) Consumer & 0.899 & 0.269 & 11.168 & 1 & 0.001 & 2.456 \\
\hline Dissatisfaction & & & & & & \\
\hline & & & & & & \\
\hline \multicolumn{1}{|c|}{ Constant } & -2.424 & 0.606 & 16.009 & 1 & 0.000 & 0.809 \\
\hline
\end{tabular}

a Variable(s) entered on step 1: Consumer Dissatisfaction. 
In this study, the significance test of hypothesis 1 was performed by using SPSS program with $a=5 \%$ level. If the probability value is $>0.05$, the proposed hypothesis will be rejected and if the probability value is < 0.05 , we will accept the proposed hypothesis. In Table 2 , it shows that the consumer dissatisfaction constant and variables are statistically significant, which the constant has a value of -2.424 and the consumer dissatisfaction variable has a value of 0.899 and both variables' $\mathrm{p}$ values are $<0.05$. It means there is a significant relationship between customer dissatisfaction and brand switching decisions. Therefore, the proposed hypothesis 1 in this study is accepted.

Meanwhile in testing the hypothesis 3, which is to analyze the presence or absence of the effect of sales promotions on brand switching decision of GSM card products, the logistic regression analysis reveals results as follows.

Table 3: Logistic Regression Analysis of the Effect of Sales Promotion on Brand Switching Decision GSM Prepaid Card Products

\begin{tabular}{|c|c|c|c|c|c|c|}
\hline & B & S.E & Wald & df & Sig. & Exp(B) \\
\hline Step (1a) Sales & 0.790 & 0.201 & 15.489 & 1 & 0.000 & 2.203 \\
\hline Promotion & & & & & & \\
\hline & & & & & & \\
\hline Constant & -2.573 & 0.560 & 21.093 & 1 & 0.000 & 0.076 \\
\hline
\end{tabular}

a Variable(s) entered on step 1: Sales Promotion.

From the information given in Table 3 , we can conclude that sales promotion influences the brand switching promotion, which is shown by significant $\mathrm{p}$ value $(<0.05)$ for both variables, i.e. sales promotion $(\beta=0.790)$ and constant $(\beta=-2.573)$. Meanwhile, the result of the second hypothesis testing, which are to test whether the need to find variation moderates the relationship between customer dissatisfaction and brand switching decision or not, reveals that need of the variety seeking has moderated the effect of customer dissatisfaction on brand switching decision as follows.

Table 4: Logistic Regression Analysis of the Moderating Effect of Need of Variety Seeking on the Relationship between Customer Dissatisfaction and Brand Switching Decision

\begin{tabular}{|l|c|c|c|c|c|c|}
\hline & B & S.E & Wald & df & Sig. & $\operatorname{Exp(B)~}$ \\
\hline $\begin{array}{l}\text { Step (1a) Customer } \\
\text { Dissatisfaction }\end{array}$ & 3.377 & 1.181 & 8.174 & 1 & 0.004 & 29.274 \\
\hline Need of Variety Seeking & 3.698 & 1.088 & 11.543 & 1 & 0.001 & 40.353 \\
\hline Moderation & -1.050 & 0.455 & 5.324 & 1 & 0.021 & 0.350 \\
\hline \multicolumn{1}{|c|}{ Constant } & & & & & & \\
\hline & -11.088 & 2.775 & 15.967 & 1 & 0.000 & 0.000 \\
\hline
\end{tabular}

a Variable(s) entered on step 1: Customer Dissatisfaction, Need of Variety Seeking, Moderation.

Based on information in Table 4, the significant p-values for all variables are < 0.05 ; therefore, we can conclude that need of the variety seeking has moderated the effect of customer dissatisfaction on brand switching decision. This moderating effect has weakened the relationship between customer dissatisfaction and brand switching decision, which is shown by $\beta$ value $=-1.050$.
Consequently, in order to explore and explain more deeply in this moderating effect, we made a subgroup analysis.

The purpose of subgroup analysis in this study is to clarify the role of moderating variables of need to seek the variation on the relationship of consumer dissatisfaction and the brand switching decision. There two 
stages needed in this analysis, there are, firstly, to find the average value of the total number of variety seeking, then once obtained an overall average value, secondly, to divide the respondents into two groups. The first group is the group that has an average value of the variety seeking that is below the stated average value, which is categorized as the low involvement group. The second group is one that has average value above the stated average value, or high involvement group.
In Table 5, the result reveals that the low level of needs to find variation does not moderate the relationship of consumer dissatisfaction and the brand switching decision, because in Table 5 , consumer dissatisfaction has a significant influence on brand switching decision. Therefore, it can be concluded that brand-switching decisions are made by consumers who have a low level of need to seek the variation due to their dissatisfaction on the currently used GSM card.

Table 5: Subgroups Analysis of the Moderating Effect of Low Level of Variation Seeking on the Relationship between Consumer Dissatisfaction and Brand Switching Decision

\begin{tabular}{|c|c|c|c|c|c|c|}
\hline & B & S.E & Wald & df & Sig. & $\operatorname{Exp(B)~}$ \\
\hline Step (1a) Low Level of & 1.266 & 0.384 & 10.871 & 1 & 0.001 & 3.547 \\
\hline Customer Dissatisfaction & & & & & & \\
\hline & & & & & & \\
\hline \multicolumn{1}{|c|}{ Constant } & -3.650 & 0.875 & 17.385 & 1 & 0.000 & 0.026 \\
\hline
\end{tabular}

a Variable(s) entered on step 1: Low Level of Customer Dissatisfaction. Subgroup Low Level of Variety Seeking

In Table 6, the study finds that the high level of needs to seek the variation moderates the relationship of consumer dissatisfaction and the brand switching decision, which the moderating effect has weakened the relationship. Table 6 also reveals that the effect of consumer dissatisfaction on the brand switching decision becomes insignificant when a high level of the variety seeking takes place. It can be concluded that brand switching decisions arise due to the need to seek the variation. In Table 6 , the obtained beta asset value of customer dissatisfaction is 1.266 and then this value decreases to 0.419 in Table 5 , and the influence of consumer dissatisfaction on the brand switching decision becomes insignificant.

Table 6: Subgroups Analysis of the Moderating Effect of High Level of Variation Seeking on the Relationship between Consumer Dissatisfaction and Brand Switching Decision

\begin{tabular}{|c|c|c|c|c|c|c|}
\hline & B & S.E & Wald & df & Sig. & Exp(B) \\
\hline Step (1a) High Level of & 0.419 & 0.387 & 1.172 & 1 & 0.279 & 1.521 \\
\hline Customer Dissatisfaction & & & & & & \\
\hline & & & & & & \\
\hline \multicolumn{1}{|c|}{ Constant } & -0.825 & 0.878 & 0.882 & 1 & 0.348 & 0.438 \\
\hline
\end{tabular}

a Variable(s) entered on step 1: High Level of Customer Dissatisfaction. Subgroup High Level of Variety Seeking

In general, our empirical findings can be summarized as follows. 
Table 7: Summary of Hypotheses Testing

\begin{tabular}{|l|c|c|c|c|}
\hline \multicolumn{1}{|c|}{ Relationship } & Beta & Alpha & Significance & $\begin{array}{c}\text { Regression } \\
\text { Output }\end{array}$ \\
\hline $\begin{array}{l}\text { Consumer Dissatisfaction - } \\
\text { Brand Switching Decision }\end{array}$ & 0.899 & 0.05 & 0.001 & $\begin{array}{c}0.001<0.05 \\
\text { Hypothesis } 1 \\
\text { accepted }\end{array}$ \\
\hline $\begin{array}{l}\text { Sales Promotion - } \\
\text { Brand Switching Decision }\end{array}$ & 0.790 & 0.05 & 0.000 & $\begin{array}{c}0.000<0.05 \\
\text { Hypothesis } 2 \\
\text { accepted }\end{array}$ \\
\hline $\begin{array}{l}\text { Consumer Dissatisfaction - } \\
\text { Variety Seeking - Moderated by } \\
\text { Sales Promotion }\end{array}$ & -1.050 & 0.05 & 0.021 & $\begin{array}{c}0.021<0.05 \\
\text { Hypothesis 3 } \\
\text { accepted }\end{array}$ \\
\hline
\end{tabular}

\section{Discussions}

\section{Consumer Dissatisfaction Has Positively} Influenced the Brand-Switching Decision. The results of this study are consistent with theoretical model proposed by Hoyer and Ridgway (1984). In their model, which is called the exploratory purchase behavior, they state that the dissatisfaction on the previously used brand products is one of the factors causing consumer to make exploratory purchasing or brand switching. These findings also fit with the study conducted by Junaedy and Dharmmesta (2002) that find no significant relationship between consumer dissatisfaction and the brand switching decision on toiletries products. Our empirical findings have equally important strengthened and clarified prior study conducted by Sambandam and Lord (1995) on the brand switching behavior, which find customer satisfaction and dissatisfaction are directly related to the brand switching. In their study, they find a negative relationship between satisfaction and brand switching for automotive products. In addition, our study also strengthens the research conducted by Setiyaningrum (2006) that examined the effect of consumer dissatisfaction on the brand switching decision in cosmetics products.

The Need to Seek the Variation Moderates the Influence of Consumer Dissatisfaction on the Brand Switching Decision. These findings are consistent with previous research conducted by Junaedy and Dharmmesta (2002) that find the need to seek variations, as the moderating variable, has affected the relationship between consumer dissatisfaction and the brand switching decision in toiletries products, which are considered falling into the consumers' low involvement products. Our results have also reinforced the research Raju (1980) stating that the need for seeking the variation is a behavior that is not always caused by discontent alone, but also it is seen as a manifestation of the desire of consumers to conduct exploration in purchasing behavior. Therefore, consumers, who are not satisfied and have a low level of need to seek the variation, will make the brand-switching decisions; meanwhile, the satisfied ones with a high need to seek the variation could equally important make the brand-switching decisions. The beta value of subgroup analysis $(-1.050)$ reveal that the moderating effect of a variety seeking variable has weakened the relationship of consumer dissatisfaction and brand switching decision.

Sales Promotion Has a Positive Effect on Brand Switching Decision. The result is in line with research conducted by Nagar (2009) who finds that the positive effect of sales promotions on brand switching decision in soap detergent and shampoos products. This finding also strengthens prior research conducted by Schindler (1984) on the possibility of trying a brand as the effect of sales promotion. Our results as well support the finding of Raju and Hastak 
(1983) that find the effects of the transaction on the purchase because of the promotion. The results showed that sales promotion not only has a positive effect on intention to try a brand, but they also serve as an effective element to block negative thoughts that may arise toward a brand.

\section{Managerial Implications}

Maintaining customers is an important thing for marketers because the cost of marketing activities issued by the GSM prepaid card service providers to attract new customers is much greater than the costs incurred to maintain existing customers (Kotler and Keller, 2009). The rapid technological change, the emergence of new competitors with high sales promotion activity, and more innovative technologies have provided to consumers to have more choices and lead them to make brand switching. This condition, surely has forced marketers to develop a marketing strategy that is more efficient and effective in order to retain customers and do not close the possibility to create new customers.

Our research findings have provided some important insights, such as the dissatisfaction felt by consumers has positively influenced the brand switching decision. Therefore, the company needs to review all factors that can increase customer satisfaction both in terms of product quality improvement, as well as in quality of service. Marketers also need to communicate the quality of product and quality customer service to existing and prospective new customers. It is because consumers, who are satisfied, tend to keep using the same brand and even invite other customers to use the same brand of product.

In this study, we also find that the need to seek the variation has also affected on consumers' brand switching decision, therefore, it is necessary for marketers to know new variations desired by consumers toward the use of their products' brands today. Marketers need to do new developments in their offered product, thus they can meet the consumers' needs and desires. We also find that sales promotions affect the consumers' brand switching decision. It means that marketers need to know in certain forms how sales promotion influence consumers' brand switching decision. Marketers must be able to influence consumer-purchasing patterns by conducting more sales promotions programs, such as bonuses, incentives, rebates and others.

\section{Conclusion}

Generally, our empirical findings have supported prior studies. The study finds consumer dissatisfaction affects positively on brand switching decision, which it means that dissatisfied consumers will try to find information on other products they consider and perceive have the added-value and in line with their expectations, and they may stop buying a product or influence others not to buy. We also find that sales promotions are positively related to branding switching decision. Meanwhile, the need of the variety seeking moderates the relationship between customer dissatisfaction and brand switching decision, which the presence of low level of need to seek the variation has weakened this relationship. At the same time, our study has several limitations, such as the limited number of samples, the absent from product category as the independent variable as it has been done in prior studies, and the need of integrating level of income as the moderating variable. These limitations are equally important opened to be extended in further studies in the different contexts.

\section{References}

Achmad, R. N. Indosat Is Struggling to Reduce the Churn Rate in Young and New Customers (in Indonesian; Indosat Tekan Churn Rate Pelanggan Muda). Detiknet.com. [Online], [Retrieved September 13, 2011], http://us.detikinet.com/read/2011/06/10/ 185044/1657962/328/indosat-tekan-churnrate-pelanggan-muda 
Assael, H. (2004). 'Consumer Behavior and Marketing Action,' 6th Ed, Cincinnati $\mathrm{OH}$; South Western College Publishing.

Baumgartner, H. \& Steenkamp, J.- B. E. M. (1996). "Exploratory Consumer Behavior Buying Behavior: Conceptualization and Measurement," International Journal of Research in Marketing Vol. 13, 121-137.

Cronin, J. J. \& Taylor, A. S. (1994). "SERVPERF Versus SERVQUAL: Reconciling PerformanceBased and Perceptions-Minus-Expectations Measurement of Service Quality," Journal of Marketing Vol. 58 (January), 125-131.

David, M., La Barbera, P. \& Aiello, A. (1996). 'When Consumers Switch Brands,' Psychology \& Marketing Spring Vol. 4 Issue 1, 17-48.

Degeratu, A. M. (1999). 'Why Do Some Consumers Switch: Is it Variety Seeking or More Forgetting?,' eBusiness Research Center 401, Business Administration Building, University Park, PA 16802, PennState.

Dharmmesta, B. (1999). 'Customer Loyalty: A Conceptual Review as a Sourcebook for Researchers,' Journal of Economics and Business Indonesia 14 (3): 73-88.

Garlington, W. K. \& Shimota, H. E. (1964). "The Change Seeker Index: A Measure of the Need for Variable Stimulus Input," Psychological Reports, 14, 919-24.

Gupta, S. (1988). "Impact of Sales Promotion on When, What and How Much to Buy," Journal of Marketing Research 25 (November), 342-355.

Gupta, S., Van Heerde, H. J. \& Wittink, D. R. (2003). "Is $3 / 4$ of the Sales Promotion Bump Due to Brand Switching? No it is $1 / 3$," Center Discussion Paper - Tilburg University, No. 2003-05, 1-29.

Gustafssons, A., Johnson, M. D. \& Roos, I. (2005). "The Effects of Customer Satisfaction, Relationship Commitment Dimensions, and
Triggers on Customer Retention," Journal of Marketing Vol. 69 (October), 210-218.

Hair, J. F. (2006). Multivariate Data Analysis, 6th ed, Upper Saddle River, New Jersey, Prentice Hall, Inc.

Hawkins, S. A. \& Hoch, S. J. (1992). "LowInvolvement Learning: Memory without Evaluation," The Journal of Consumer Research Vol. 19 No. 2, 212-225.

Hoyer, W. D. \& MacInnis, D. J. (2001). Consumer Behaviour. 2nd ed., Boston: Houghton Mifflin Company.

Hoyer, W. D. \& Ridgway, N. M. (1984). "Variety Seeking As an Explanation for Exploratory Purchase Behavior: A Theoretical Model," Advances in Consumer Research Vol. 11, 114-119.

Junaedy, S. \& Dharmmesta, B. S. (2002). 'The Influence of Consumer Dissatisfaction, Characteristics Product Category, and Variety Seeking on Brand Switching,' Journal of Economics and Business Indonesia Vol. 17 No. 17(1), 91-104.

Kahn, B. E. \& Louie, T. A. (1990). "Effects of Retraction of Price Promotions on Brand Choice Behavior for Variety-Seeking and Last-Purchase-Loyal Consumers," Journal of Marketing Research Vol. 27 No. 3, 279-289.

Keaveney, M. S. (1995). "Customer Switching Behavior in Service Industries: An Exploratory Study," The Journal of Marketing Vol. 59 (April) No. 2, 71-82.

Kotler, P. \& Keller, K. L. (2009). Marketing Management 13th Ed. Upper Saddle River, New Jersey: Pearson Education, Inc.

Lau, G. T. \& Lee, S. H. (1999). "Consumers' Trust in a Brand and the Link to Brand Loyalty," Journal of Market Focused Management Vol. 4, 341-370. 
Leuba, C. (1955). "Toward Some Integration of Learning Theories: The Concept of Optimal Stimulation," Psychological Reports, 1, 27-33.

Lin, C.- T., Wang, S.- M. \& Hsieh, H.- Y. (2003). 'The Brand-Switching Behaviour of Taipei Female Consumers when Purchasing U-V Skincare Products,' International Journal of Management Vol. 20 No. 4 December, 443452.

Mehrabian, Albert \& Russell, James A. (1974), An Approach to Environmental Psychology, Cambridge, Massachusetts: The MIT Press.

Nagar, K. (2009). "Evaluating the Effect of Consumer Sales Promotions on Brand Loyal and Brand Switching Segments," Journal of Business Perspective (October-December) No. 4. Vol. 13, 35-48.

Penney, R. K. \& Reinehr, R. C. (1966). "Development of a Stimulus-Variation Seeking Scale for Adults," Psychological Reports, 18, 631,38.

Raju, P. S. (1980). "Optimum Stimulation Level: It's Relationship to Personality, Demographics, and Exploratory Behavior," The Journal of Consumer Research Vol. 7, No.3, December, 272-282.

Raju, P. S. \& Hastak, M. (1983). "Pre Trial Cognitive Effects of Cents off Coupons," Journal of Advertising Vol. 12 No. 2, 24-33.

Sambandam, R. \& Lord, R. K. (1995). "Switching Behavior in Automobile Markets: A Consideration-Sets Model," Journal of the Academy of Marketing Science Vol. 23, 57-65.

Setiyaningrum, A. (2006). 'Effect of Consumer Dissatisfaction and Needs Variety Seeking Decision on Brand Switching,' Thesis Faculty of Economics and Business UGM Yogyakarta (unpublished).

Sood, S. \& Kathuria, P. (2004). 'Switchers and Stayers: An Empirical Examination of Customer Base of an Automobile Wheel Care
Center,' Journal of Services Research Vol. 4 No. 2, 75-90.

Srinivasan, M. (1996). 'New Insights Into Switching Behavior: Marketers can now put a numerical value on loyalty,' Marketing Research: A Magazine of Management \& Application, Vol. 8 No. 3 September, 27-33.

Srinivasan, N. \& Ratchford T. B. (1991). "An Empirical Test of a Model of External Search for Automobiles," The Journal of Consumer Research Vol. 18 No. 2, 233-242.

Van trijp, H. C. M., Hoyer, W. D. \& Inman, J. J. (1996). "Why Switch? Product Category: Level Explanations for True Variety-Seeking Behavior," Journal of Marketing Research 34 August, 281-292.

Wahono, T. (2010). The Total of Cellular Phone Customers in Indonesia Reach 180 Million (in Indonesian: Jumlah Pelanggan Seluler Indonesia 180 juta), Kompas.com. [Online], [Retrieved September 27, 2011], http://tekno.kompas.com/read/2010/07/14 /13572832/Jumlah.Pelanggan.Seluler. Indonesia.180.Juta

Yandiana, S. (2008). Analysis of Effectiveness of XL Cellular Card Product Advertisement Using Consumer Decision Model Approach, Master thesis (unpublished), Bogor Agricultural University, Bogor - Indonesia.

Zuckerman, M., Kolin, E. A.; Price, L. \& Zoob, I. (1964), "Development of a Sensation Seeking Scale," Journal of Consulting Psychology, 28, 477-82. 